\title{
Integrated seismic risk analysis using simple weighting method: the case of residential Eskişehir, Turkey
}

\author{
E. Pekkan, M. Tun, Y. Guney, and S. Mutlu \\ Earth and Space Sciences Institute, Anadolu University, Eskişehir, Turkey \\ Correspondence to: E. Pekkan (epekkan@anadolu.edu.tr)
}

Received: 16 September 2014 - Published in Nat. Hazards Earth Syst. Sci. Discuss.: 13 November 2014

Revised: 5 March 2015 - Accepted: 28 April 2015 - Published: 2 June 2015

\begin{abstract}
A large part of the residential areas in Turkey are at risk from earthquakes. The main factors that threaten residential areas during an earthquake are poor quality building stock and soil problems. Liquefaction, loss of bearing capacity, amplification, slope failure, and landslide hazards must be taken into account for residential areas that are close to fault zones and covered with younger sediments. Analyzing these hazards separately and then combining the analyses would ensure a more realistic risk evaluation according to population density than analyzing several risks based on a single parameter.

In this study, an integrated seismic risk analysis of central Eskişehir was performed based on two earthquake related parameters, liquefaction and amplification. The analysis used a simple weighting method. Other earthquake-related problems such as loss of bearing capacity, landslides, and slope failures are not significant for Eskişehir because of the geological and the topographical conditions of the region. According to the integrated seismic risk analysis of the Eskişehir residential area, the populated area is found to be generally at medium to high risk during a potential earthquake.
\end{abstract}

\section{Introduction}

Population growth accompanied by economic and social development triggers the growth of urban residential areas in particular. This brings about the need for the design of new residential areas and the establishment of new city centres. While planning new residential areas the protection of existing and planned areas against potential disasters is of vital importance. When the location and recent history of Turkey are taken into consideration, earthquakes are seen to be the main risk factor to be taken into consideration in the design of new residential areas.

The balance between human activity and the environment is often disturbed by urbanization efforts (Mulder, 1996; Topal et al., 2003; Mulder and Pereira, 2009; Park et al., 2011; Erol and Topal, 2012). The decrease of this imbalance and modification of its effects on the environment are possible through multivariate urban planning (Erol and Topal, 2012; Bell, 1998; Bell et al., 1987). Geological and geotechnical data are also of great importance in terms of identification, control, vitiation, and prevention of geological hazards (Erol and Topal, 2012; Bell et al., 1987; Bell and Pettinga, 1985; Legget, 1987; Hake, 1987; Rau, 1994; Dai et al., 1994, 2001; Van Rooy and Stiff, 2001; Kılıç et al., 2006; Ulamış and Kılıç, 2008; Marker, 2009; Bell et al., 2009). In multivariate urban planning, multivariate soil risk analysis is also crucial for the prevention of potential impacts and for ground settlement.

Eskişehir is a rapidly growing city located in northwestern Turkey, in a second-degree seismic zone that is at risk of earthquakes (Fig. 1). Porsuk Creek which is also a branch of the Sakarya River is the main river in the Eskişehir area. Porsuk Creek divides the Eskişehir residential area into two equal parts; it flows through the city from the south-west, running through the city centre and exiting from the east. Another important stream in the study area is the Sarısu Creek, a tributary of the Porsuk Creek. Sarisu Creek, which runs from west to east, is effective in carrying and depositing alluvial sediments, which form the ground surface of the northwestern city centre. On 20 February 1956, an earthquake of magnitude 6.4 took place in the Eskişehir city centre. The earthquake heavily damaged 393 buildings in the city, rendering them unusable (Öcal, 1959). Eskişehir has been clas- 


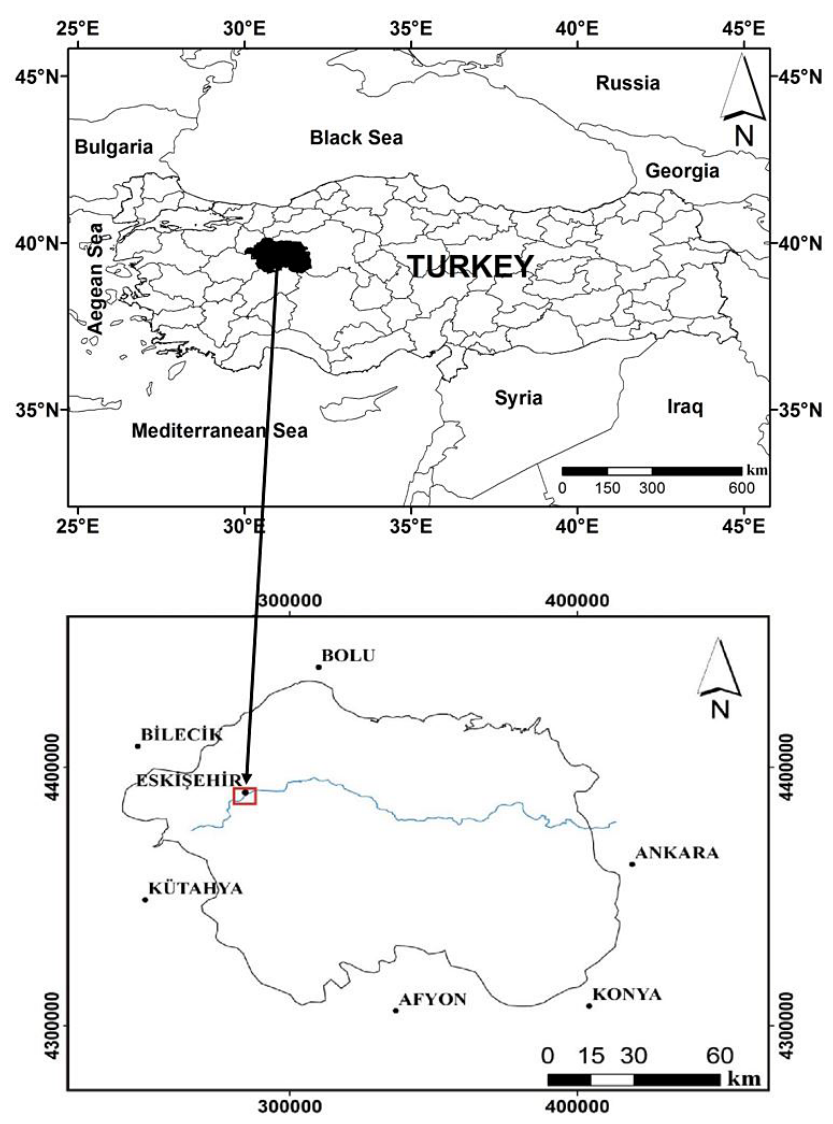

Figure 1. Site location map of the study area.

sified as a second-degree seismic hazard zone according to the 1997 Bylaw on Buildings to be Constructed in Disaster Areas (ABYYHY, 1997).

During earthquakes, the ground conditions of residential areas are among primary reasons for damage, as is poor quality building stock. The damage caused by local ground conditions during an earthquake include the amplification impact of local conditions on seismic waves, the loss of shear strength in a subsurface layer due to liquefaction, strong ground displacements resulting from slope failures and landslides, and foundation settlements driven by ground compaction (Beliceli, 2006). Since Eskişehir's residential area largely sits on level land, the risk of slope failure and landslide is much lower than the risk of earthquake. The reason for the variation of earthquake-induced damage across the region is soil liquefaction and amplification due to soil characteristics. Therefore, soil liquefaction analyses were conducted on 87 wells with a depth of $30 \mathrm{~m}$ in Eskişehir and its surroundings, and an integrated hazard assessment of the soil structure during an earthquake was developed through site amplification characteristics derived from 23 seismic refractions, again using the 87 wells at a depth of $30 \mathrm{~m}$.

In this study, the liquefaction index (LI) values acquired through the standard penetration test (SPT) and the method proposed by Iwasaki et al. $(1978,1982)$ are classified based on the degrees of liquefaction potential proposed by Sonmez (2003).

The site amplification map, on the other hand, was developed by using $\mathrm{Vs}_{30}$ values derived from seismic refraction measurements and empirical $\mathrm{Vs}_{30}$ values derived from the SPT values of the wells in the study area, using the methodology of Borcherdt et al. (1991) within the context of another study carried out by Mutlu (2012). This study classifies the degree of seismic amplification potential of soil sites.

\subsection{Study area}

The study area was selected as the area covered by ancient and recent alluvial formations, taking the residential areas into consideration, and marked by a frame on the geological map (Fig. 2). While loose sand and low plasticity levels are found at the recent alluvial unit, ground water levels are low because the city centre is located along the banks of the Porsuk and Sarisu Creeks. Thus, areas with waterlogged loose sand and low plasticity levels pose a liquefaction risk (Bayrakçı et al., 2013).

The Eskişehir plain is covered with loose sedimentary units which are transported by Porsuk and Sarısu Creek. Groundwater levels around the Porsuk and the Sarısu Creek groundwater table are getting closer to the surface while far from the rivers they are getting deeper (Fig. 2). In general the groundwater depth changes between -5 and $-10 \mathrm{~m}$ around the city centre.

The geology of the study area, Eskişehir and its surroundings, consists of five geological formations from old to young, which are the Karkin formation, Mamuca formation, Porsuk formation, Ilica formation, and Akcay formation (Fig. 2) (Tokay and Altunel, 2005). The city is underlain by the ancient alluvial (Akcay) formation of the Pleistocene age and the recent alluvial (Porsuk) formation of the Pliocene age, discordant to the underlying rock units and Middle-toUpper Miocene deposits. The Akcay formation is comprised of loosely consolidated clay, silt, sand, and gravels. The formation is in the form of terraces at the heights around the river basin. Porsuk formation, on the other hand, is made up of the sediments carried and deposited by the Sarisu Creek and the Porsuk Creek and its branches (Tosun et al., 2007). This unit overlays a large part of the Eskişehir city centre (Fig. 3).

\subsection{Seismicity of the study area}

The province of Eskişehir is included in the İzmir-EskişehirAnkara tectonic zone which is formed by tectonism that developed with the covering of the Tethys Ocean at the end of the Triassic. A fault zone occurred at Eskişehir as a result of these tectonisms. The Eskişehir zone, lying in between Uludağ to the west and Kaymaz to the north, is a right sided normal fault zone separating the Aegean - western 


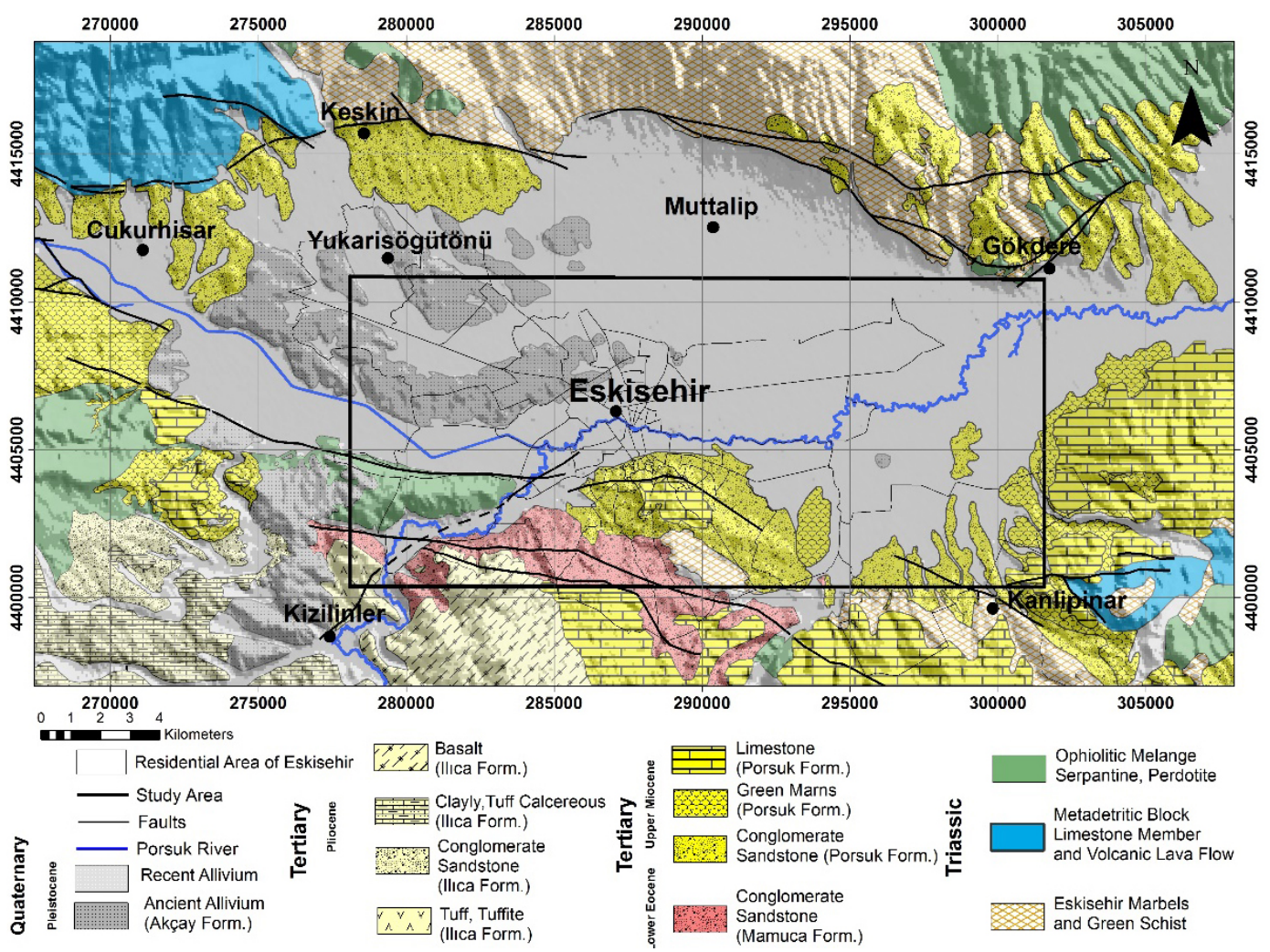

Figure 2. The geological map of Eskişehir (modified from Orhan et al., 2007).

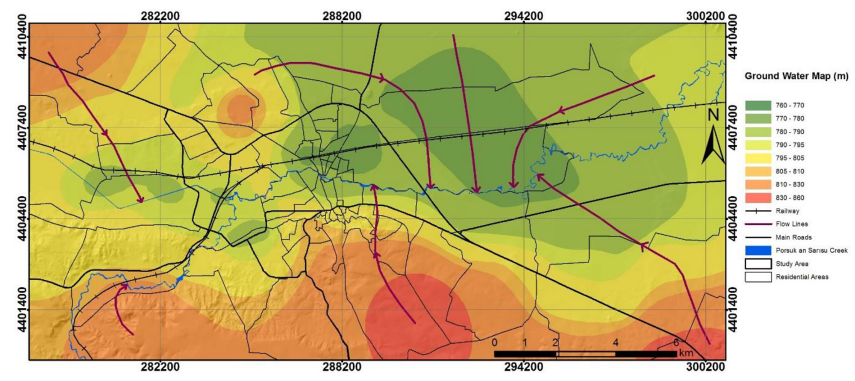

Figure 3. Groundwater table map obtained from the drill holes.

Anatolian block from the mid-Anatolian block at its northeast. This fault zone is represented by fault segments varying from the east-west and north-south directions. The faults formed during and after the storing observed at Pleistocene and Holocene units, indicate that the Eskişehir fault zone has been active since at least the Pleistocene Age. At least 14 earthquakes with a magnitude of 4 or higher have occurred in or around the Eskişehir zone in the 20th century, and the 6.4 magnitude earthquake of 20 February 1956 was the most dangerous. The fault zone is formed as following segments along the İnönü-Oklubal1-Turgutlar-Sultandere route (Fig. 4) (Altunel and Barka, 1998).

The province of Eskişehir is classified as the second degree hazard zone according to the earthquake map of Turkey pre- pared in 1996 by the General Directorate of Natural Disasters of the Ministry of Public Works and Settlement. The Eskişehir fault zone, which is about $80 \mathrm{~km}$ from the north Anatolian fault zone (NAFZ) (Onur et al., 2007), provided an earthquake of 6.4 in magnitude in 1956. This earthquake affected infrastructure in the Eskişehir, Bilecik and Bozüyük areas (Öcal, 1959). In addition, during the Kocaeli (NAFZ) earthquake of 17 August 1999, a building collapsed and many other buildings were seriously damaged in Eskişehir city centre (Akdeniz et al., 2011).

Recent studies (Setiyoglu et al., 2015) of the seismicity of the study area indicate the presence of a $40 \mathrm{~km}$ long fault dominated by positive flower structures. Results obtained from seismic refraction surveys around the Eskişehir residential area further demonstrated that the 1956 Eskişehir earthquake and the recent 1990, 2010, and 2013 earthquakes occurred on or near the Çukurhisar-Sultandere segment, which might be evaluated as a potential seismic hazard source for the Eskişehir settlement (Fig. 5).

\section{Methodology}

\subsection{Site amplification}

Site amplification refers to the increase in amplitude of earthquake-induced seismic waves while they pass through 


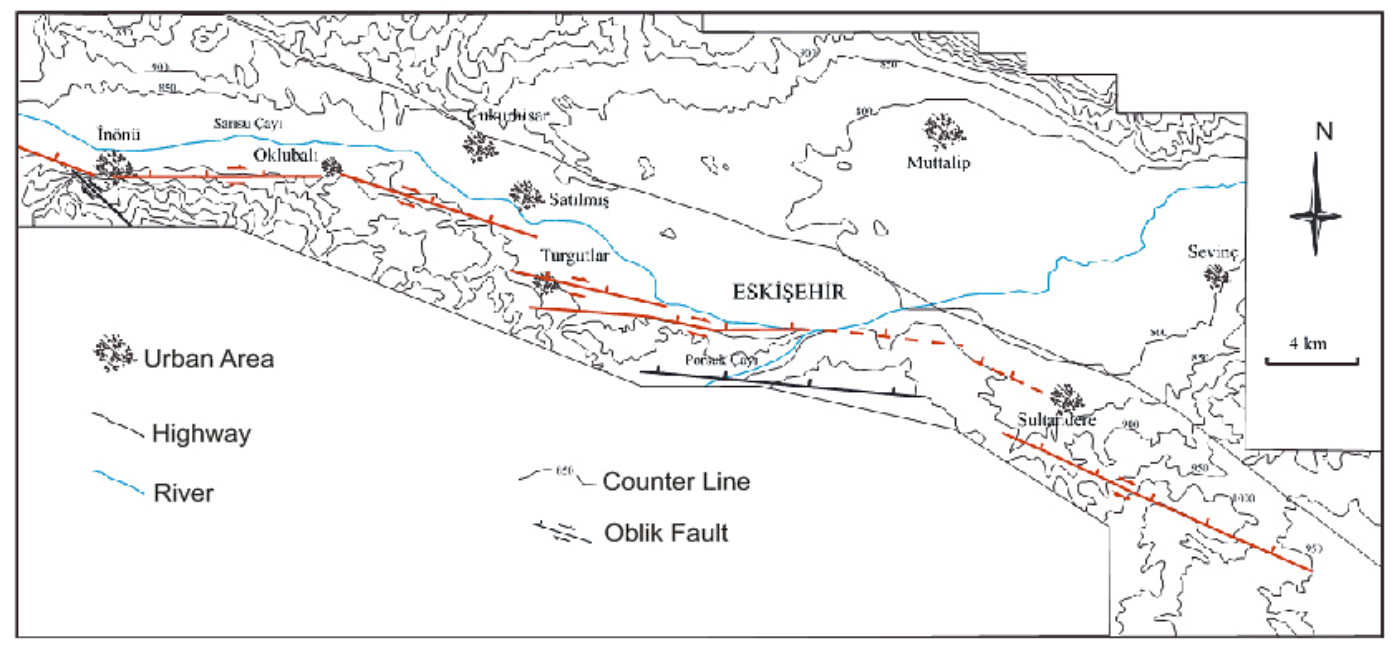

Figure 4. Tectonic map of Eskişehir (Altunel and Barka, 1998).

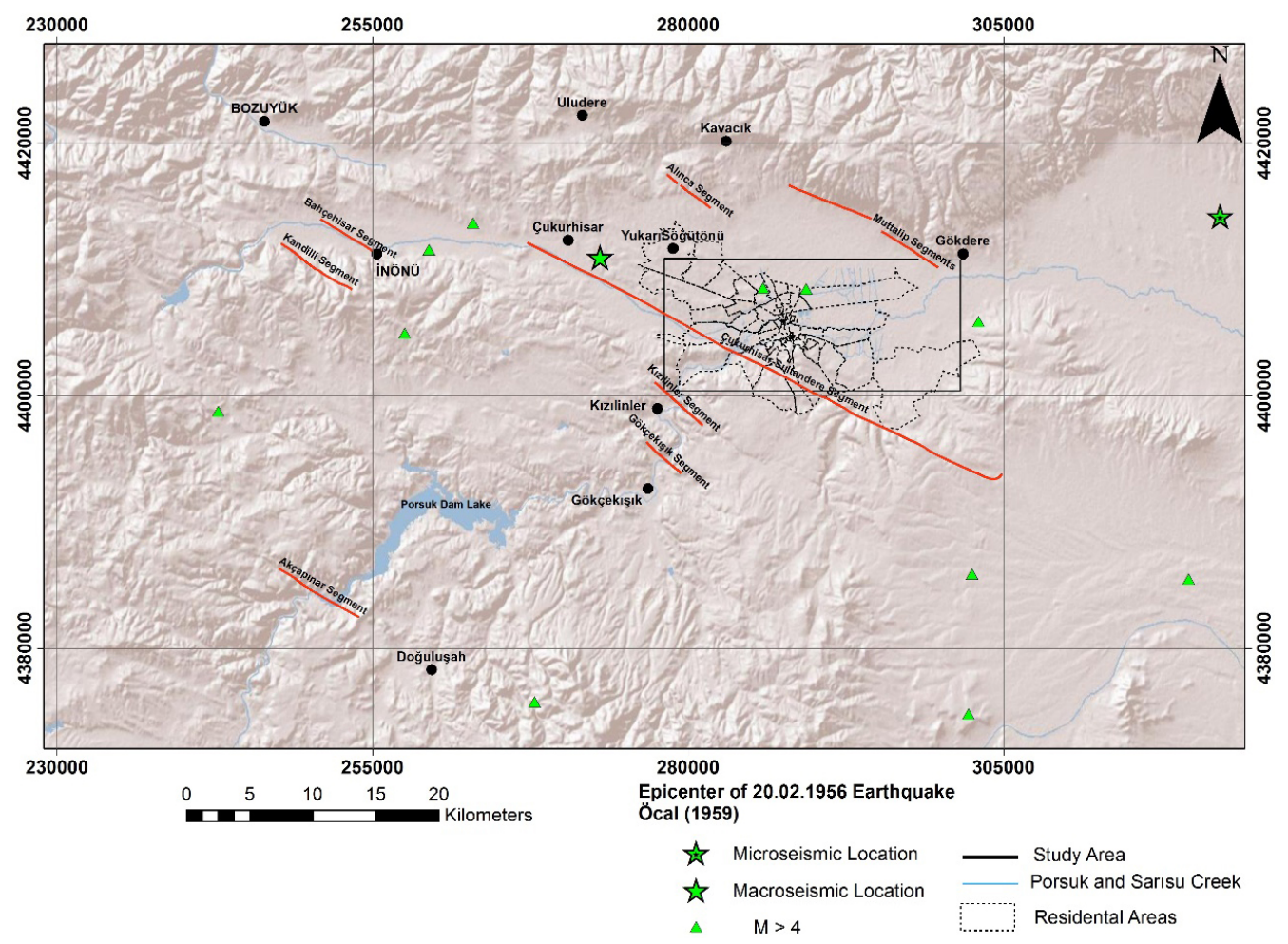

Figure 5. Seismotectonics of the study area (simplified from Seyitoğlu et al., 2015).

soft subsurface soil layers. It has been defined as a function of shear wave velocity for the soft layer of the upper $30 \mathrm{~m}$ of a surface (Vs30) (Borcherdt et al., 1991; Midorikawa, 1987; Joyner and Fumal, 1984). There are several ways to assess the site amplification hazard of a selected place. According to Abrahamson and Silva (2008), the coefficient of site amplification is a function of the average shear wave velocity over the upper $30 \mathrm{~m}$ of soil. Another approach recommended by Borcherdt (1994), assumes that the soil sites with a pro- file that displays a wide range of shear wave velocity have typical behaviours that represent a certain site class. In this method, empirical amplification factors are calculated by the potential acceleration spectrum at the bedrock level, features of the spectrum profile and the average shear wave velocity measured over the upper $30 \mathrm{~m}$ (Ansal et al., 2011). The site amplification hazard in our present study area may also occur in the ancient alluvial (Akcay) formation of the central, 
western and north-western parts of the city, as well as in the recent alluvial (Porsuk) formation.

$\mathrm{Vs}_{30}$ has been utilized widely in several applications, such as investigating site-specific effects in ground motion prediction equations (Abrahamson and Silva, 2008) and as the basis for specifying site classes in building codes (Dobry et al., 2000; Building Seismic Safety Council, 2003; Eurocode 8, 2004, cited in Boore et al., 2011). Vs 30 is a simple metric that can be obtained at relatively low cost compared to more detailed descriptions of site characteristics, and it is correlated with site amplification, although it cannot capture all of the physics controlling site amplification as indicated in several studies (e.g. Mucciarelli and Gallipoli, 2006; Castellaro et al., 2008; Lee and Trifunac, 2010; Boore et al., 2011). Recognizing the limitations of the parameter, as an engineering approach it is thought to be useful in low cost microzonation studies to determine the amplification of the area using real earthquake data.

Figure 6 shows that the site amplification formula based on shear wave velocity of Borcherdt et al. (1991) gives a higher amplification value compared to the formulas of other researchers. In other words, the site amplification calculation using the formula of Borcherdt et al. (1991) provides a more conservative risk assessment. This study used the formula of Borcherdt et al. (1991) in the site amplification analysis based on the shear wave velocity.

$\mathrm{Vs}_{30}$ may be calculated empirically depending on different site categories by using the standard penetration test values of wells (SPT-N) (e.g. Jafari et al., 1997; İyisan, 1996; Lee, 1990; Seed and Idriss, 1982; Ohta and Goto, 1978; Imai, 1977; Imai et al., 1975; Ohba and Toriumi, 1970) or directly by the seismic refraction method.

Soil with a $\mathrm{Vs}_{30}$ velocity below $700 \mathrm{~m} \mathrm{~s}^{-1}$ is defined as soft stratum. Formations with shear wave velocities above $700 \mathrm{~m} \mathrm{~s}^{-1}$ are considered as "engineering rock" (Beliceli, 2006). A site amplification risk is made for formations whose $\mathrm{Vs}_{30}$ value is below $700 \mathrm{~m} \mathrm{~s}^{-1}$.

In areas underlain by young geological sediments, the site amplification generated by earthquake-induced ground motions is correlated with the shear wave velocity. Based on this correlation, the NEHRP (National Earthquake Hazards Reduction Program) adopted a classification, also used in the 1997 UBC (Uniform Building Code), based on the average shear wave velocity for the upper $30 \mathrm{~m}$. of the soil. The west and Central US State Geologists Earthquake Consortium (CUSEC) has also produced an amplification classification based on this classification, based on the average shear wave velocity for unconsolidated sediments. The present sample study of Eskişehir's central residential area uses amplification values varying between 0 and 3.5. In weighting adjustments, the higher the site amplification values based on the site amplification factors produced by the CUSEC the more amplification; thus the hazard increases. The classification of site amplification factors are shown in Table 1.

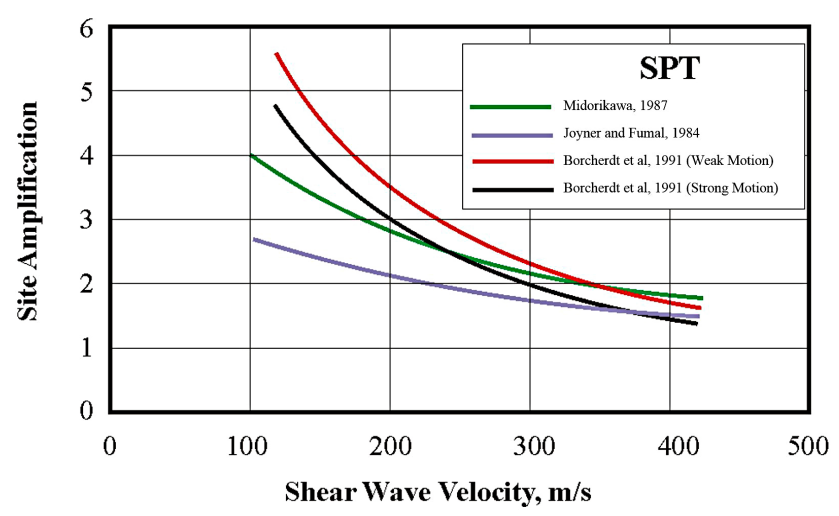

Figure 6. Site amplification calculation based on shear wave velocity (Beliceli, 2006).

Table 1. Amplifier classification table.

\begin{tabular}{llll}
\hline $\begin{array}{l}\text { NEHRP } \\
\text { site } \\
\text { class }\end{array}$ & $\begin{array}{l}\text { Physical description } \\
\text { (Borcherdt, 1994) }\end{array}$ & $\begin{array}{l}\text { Expected site } \\
\text { amplification } \\
\text { (CUSEC) }\end{array}$ & $\begin{array}{l}\text { Site } \\
\text { amplification } \\
\text { class }\end{array}$ \\
\hline A & Hard rock & $0.8-1.0$ & None \\
B & Firm to hard rock & $1.0-1.3$ & Low \\
C & Gravelly soils and soft rock & $1.3-1.7$ & Moderate \\
D & Stiff clays and sandy soils & $1.7-2.4$ & High \\
E1 & Soft soils ( $\leq 37$ m thick) & $2.4-3.5$ & Very high \\
E2 & Soft soils (>37 m thick) & $2.4-3.5$ & \\
\hline
\end{tabular}

\subsection{Soil liquefaction}

The damage and loss of life caused by earthquakes are more concentrated in residential areas underlain by soft soils (Borcherdt, 1994). Earthquake-induced liquefaction appears on sandy soil whereas site amplification occurs on loose soils such as alluvial soils, including sands.

Although several liquefaction analyses have been completed by the other researchers in the area, like Tosun et al. (2011), the main difference of the work reported here is the extent of the study area that covers all districts of Eskişehir. The present data sets are also more resolved when compared by Tosun et al. (2011) which employed shallow drill holes with a mean depth of $10 \mathrm{~m}$, while the present study utilized 87 drill holes and calculations were made through a depth of $20 \mathrm{~m}$.

The liquefaction potential index (LI) was first proposed by Iwasaki et al. $(1978,1982)$ and tested at 63 liquefied and 22 non-liquefied sites through six earthquakes that occurred in Japan between 1891 and 1978. Their proposed LI value formula is given in Eq. (1).

$$
\mathrm{LI}=\int_{0}^{20} F(z) W(z) \mathrm{d} z .
$$


In the equation, the $F(z)$ value reflects the severity level while $W(z)=10-0.5 z$ represents the depth-based weighting function.

The researchers of the present project decided to use the liquefaction potential classification proposed by Sonmez (2003) (Table 2).

The $F(z)$ (severity factor), which represents the severity of liquefaction at any site, is defined by the quantitative factor of safety (FS).

$$
F(z)= \begin{cases}\mathrm{FS} \geq 1.2, & \text { "no_liquefaction" } \\ 0.95<\mathrm{FS}<1.2, & F(z)=2 \cdot 106 \cdot e^{-18.427 \mathrm{FS}} \\ \mathrm{FS} \leq 0.95, & F(z)=1-\mathrm{FS} .\end{cases}
$$

In the equation, FS is defined as the cyclic resistance ratio (CRR) divided by the cyclic stress ratio (CSR) ( $\mathrm{FS}=\mathrm{CSR} / \mathrm{CRR}$ ). In physical terms, it is a measurement of the extent to which the maximum shear strength (CSR) induced by an earthquake may resist the shear resistance of the layer to liquefaction induced by the soil layer (CRR). The FS equation is applied for earthquakes of magnitude 7.5; thus a magnitude correction factor (MDF) was produced by Seed et al. (1985) for earthquakes of different magnitudes (Eq. 3).

$\mathrm{FS}=\frac{(\mathrm{CRR})_{7.5}}{(\mathrm{CSR})} \cdot \mathrm{MDF}$.

CSR and CRR in the equation are given by Eqs. (4) and (5).

$\mathrm{CSR}=0.65 \cdot \frac{a_{\mathrm{max}}}{g} \cdot \frac{\sigma_{\mathrm{v} 0}}{\sigma_{\mathrm{v} 0}^{\prime}} \cdot r_{\mathrm{d}}$.

In this equation, $a_{\max }$ stands for the maximum horizontal acceleration on the ground surface, $\sigma_{\mathrm{v} 0}$ for the total vertical stress, $\sigma_{\mathrm{v} 0}^{\prime}$ for the effective vertical stress, $g$ for gravity acceleration, and $r_{\mathrm{d}}$ for the stress reduction factor based on depth from the surface (Seed and Idriss, 1971).

The CRR value is calculated by Eq. (5) for magnitude 7.5 earthquakes (Mollamahmutoğlu and Babuçcu, 2006). Some corrections to the raw SPT are needed in order to determine the CRR based on the SPT. These corrections rely upon the analysis based on the corrected SPT-N $\left(\mathrm{N}_{1}\right)_{60}$ proposed by Youd et al. (2001), and have been accepted worldwide.

$\mathrm{CRR}=\frac{1}{34-\left(\mathrm{N}_{1}\right)_{60}}+\frac{\left(\mathrm{N}_{1}\right)_{60}}{135}+\frac{50}{\left(10\left(\mathrm{~N}_{1}\right)_{60}+45\right)^{2}}-\frac{1}{200}$.

In accordance with the General Format for Soil and Ground Study Report issued by the Turkish Ministry of Public Works and Settlement in 2005, drilling depths cannot be less than $20 \mathrm{~m}$ in first- and second-degree earthquake zones on account of liquefaction. Since Eskişehir lies in a second-degree earthquake zone, the drilling depths used for the analyses were selected in accordance with this communique. The liquefaction analyses' calculations were made through the first $20 \mathrm{~m}$ of the drill holes, as also suggested by Iwasaki et al. (1978, 1982).
Table 2. Degrees of liquefaction potential (Sonmez, 2003).

\begin{tabular}{ll}
\hline $\begin{array}{l}\text { Liquefaction potential } \\
\text { index (LI) }\end{array}$ & $\begin{array}{l}\text { Liquefaction } \\
\text { potential }\end{array}$ \\
\hline 0 & Non-liquefiable \\
$0<\mathrm{LI} \leq 2$ & Low liquefiable \\
$2<\mathrm{LI} \leq 5$ & Moderate liquefiable \\
$5<\mathrm{LI} \leq 15$ & High liquefiable \\
$15<\mathrm{LI}$ & Very high liquefiable \\
\hline
\end{tabular}

\subsection{Simple weighting method}

The simple weighting method is a multi-criterion analysis. Eastman et al. (1995), Pettit and Pullar (1999), and Perez et al. (2003) used the weighted summation in conjunction with Boolean operations. The methods are easy to understand and intuitively appealing to decision-makers (Malczewski, 2006).

The simple weighting method involves identification of attributes that are relevant to the project, the allocation of weights to each of them to reflect their relative importance, and the allocation of scores to each option to reflect how it performs in relation to each attribute. The result is a single weighted score for each option, which may be used to indicate and compare the overall performance of options in nonmonetary terms.

This process necessarily assigns numeric values to judgments. These judgments should not be arbitrary or subjective, but should reflect scientific assessments, and should be supported by objective information.

\section{Data}

The data from the 87 drillings in central Eskişehir were derived from two separate projects. The data from 72 drillings were acquired within the context of a project titled "Micro Zoning and Hazard Assessment Studies to Mitigate Disaster Damages", supported by the Turkish Prime Ministry, while the other 15 drillings were part of the University of Anatolia's Scientific Research Project No. 0802000040. Liquefaction analyses were assessed on a total of 87 wells.

We have considered a scenario earthquake of the magnitude $M=6.4$, based on the one which actually hit Eskişehir on 20 February 1956. This magnitude is also thought to be the maximum earthquake that could happen in Eskişehir. Analyses were carried out for peak ground acceleration (PGA) levels at $0.30 \mathrm{~g}$ as established for second-degree earthquake zones (Ministry of Reconstruction and Settlement, 1996).

Amplification analyses were performed using 23 seismic refraction sections by Mutlu (2012) and 87 wells, which were also assessed within this study. 


\section{Findings}

\subsection{Site liquefaction analysis}

LI values were acquired for the drilling in the region through the liquefaction analysis proposed by Iwasaki et al. (1978, 1982) (Table 3).

The LI values set forth were interpolated by the inverse distance weighting method (IDW) and a liquefaction potential map was created for the Eskişehir city centre through the classification proposed by Sonmez (2003) (Fig. 7).

Regarding the liquefaction potential map, regions having mainly a mid-high liquefaction hazard were found in the central, western, and north-western parts of the study area. The eastern part of the region has a relatively lower liquefaction hazard (Fig. 7). A large part of the Porsuk Creek and the surrounding area was found to have a moderate liquefaction hazard. This part is where the young alluvium is thickest.

\subsection{Site amplification analysis}

Pursuant to the methodology of Borcherdt et al. (1991), amplification values calculated by shear velocities (given by both the drilling and the seismic refractions) were mapped using the IDW method (Fig. 8). Regarding the analysis, regions of high amplification - that is, having an amplification value of 1.5-1.7 according to Table 2 - are located in the recent alluvium, close to Porsuk Creek, which is at the centre of the study area and in the old alluvium in the west. The northern site is the most hazardous area, showing a "very high" amplification, the amplification value being above 1.7. Apart from the liquefaction surface, the most prominent detail is the value assigned for the ancient alluvial surface. The ancient alluvial surface, which overlays the west of the study area (Fig. 2), does not pose a liquefaction hazard, while it does show high amplification levels according to the amplification classification analysis of this study.

\subsection{Simple weighting method}

Following the assignment of the surfaces of liquefaction and site amplification, a hazard map was built based on two dynamic soil parameters through the simple weighting method (Fig. 9). The simple weighting method generates a new value by weighting multiple variables on a given ratio adjusted according to those used for the variables. During the weighting in this study, a hazard surface was created by weighting liquefaction and site amplification values by 30 and $70 \%$, respectively. The weight of the site amplification was calculated as $70 \%$, as it affects wider areas and poses more risks under dynamic conditions than liquefaction. Hazard classification for liquefaction potential was proposed by Sonmez (2003). In order to use similar classification ranges with liquefaction potential values, a standardization was applied to both the classification of amplification values and the hazard grade (Table 4).
Table 3. Liquefaction index values acquired across a $20 \mathrm{~m}$ depth.

\begin{tabular}{llll}
\hline Drilling & LI & Drilling & LI \\
\hline SK-1 & 0 & SK-45 & 0 \\
SK-2 & 0.0244 & SK-46 & 2.252 \\
SK-3 & 0 & SK-47 & 0 \\
SK-4 & 0 & SK-48 & 1.575 \\
SK-5 & 1.595 & SK-49 & 0 \\
SK-6 & 0 & SK-50 & 2.558 \\
SK-7 & 0 & SK-51 & 0 \\
SK-8 & 0 & SK-52 & 0 \\
SK-9 & 0 & SK-53 & 0.02 \\
SK-10 & 0 & SK-54 & 7.303 \\
SK-11 & 0 & SK-55 & 15.918 \\
SK-12 & 0 & SK-56 & 9.195 \\
SK-13 & 0 & SK-57 & 0.037 \\
SK-14 & 0 & SK-58 & 0 \\
SK-15 & 0 & SK-59 & 0.065 \\
SK-16 & 0 & SK-60 & 1.392 \\
SK-17 & 0 & SK-61 & 12.109 \\
SK-18 & 0 & SK-62 & 0 \\
SK-19 & 0 & SK-63 & 0.014 \\
SK-20 & 0 & SK-64 & 0 \\
SK-21 & 0.083 & SK-65 & 0 \\
SK-22 & 0.449 & SK-66 & 9.971 \\
SK-23 & 7.232 & SK-67 & 0 \\
SK-24 & 0.014 & SK-68 & 0 \\
SK-25 & 2.92 & SK-69 & 0.225 \\
SK-26 & 3.504 & SK-70 & 0 \\
SK-27 & 0 & SK-71 & 1.533 \\
SK-28 & 0.254 & SK-72 & 0.964 \\
SK-29 & 1.889 & SK-73 & 9.757 \\
SK-30 & 0.563 & SK-74 & 3.311 \\
SK-31 & 3.251 & SK-75 & 0.309 \\
SK-32 & 0.734 & SK-76 & 2.579 \\
SK-33 & 0 & SK-77 & 0.042 \\
SK-34 & 1.603 & SK-78 & 3.675 \\
SK-35 & 0 & SK-79 & 0.04 \\
SK-36 & 0 & SK-80 & 3.793 \\
SK-37 & 0 & SK-81 & 0 \\
SK-38 & 0 & SK-82 & 0 \\
SK-39 & 0 & SK-83 & 10.799 \\
SK-40 & 0 & SK-84 & 0.116 \\
SK-41 & 0 & SK-85 & 3.964 \\
SK-42 & 0 & SK-86 & 0 \\
SK-43 & 3.759 & SK-87 & 0.018 \\
SK-44 & 16.642 & & \\
\hline & & & \\
\hline
\end{tabular}

\section{Results}

According to the hazard map produced through overlaying both variables on the given ratios, more than half of the area is at mid-high hazard (Fig. 9). In particular, the northern, western, and south-western parts consist of high-hazard zones. The only areas found to be classified as very low hazard are the zones formed by lithologies that have no alluvial formations. To evaluate the seismic risk of the area, the pop- 


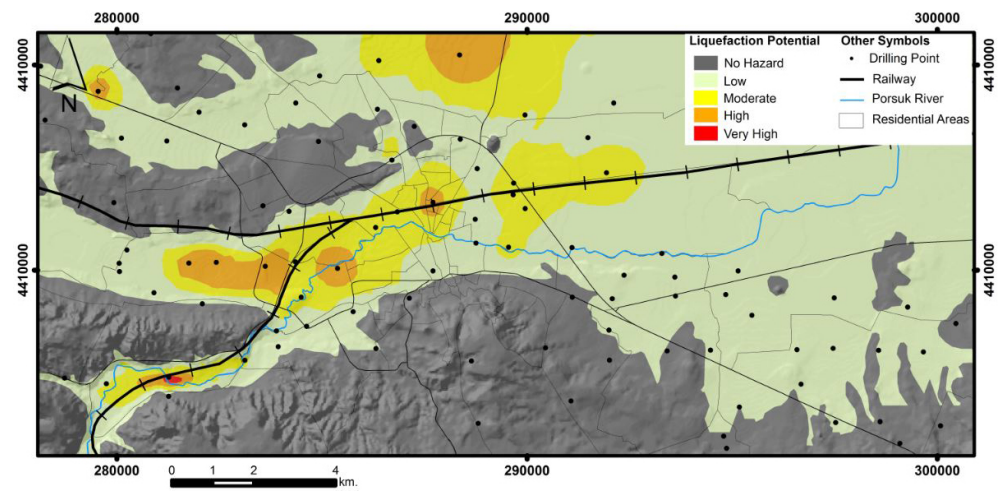

Figure 7. Liquefaction potential map acquired through the IDW method.

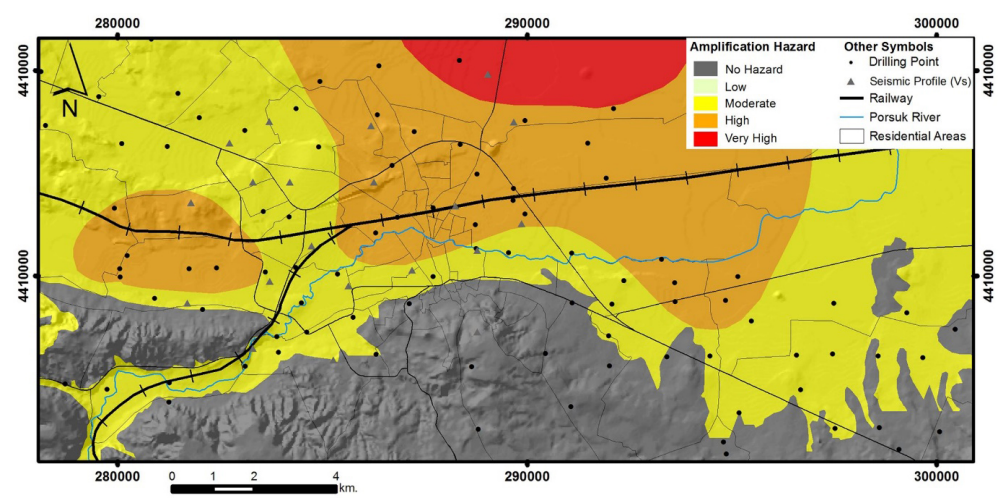

Figure 8. Amplification hazard map acquired through the IDW method.

Table 4. Classifications and simple weighting points used in the analyses.

\begin{tabular}{lclllllc}
\hline \multicolumn{2}{c}{$\begin{array}{c}\text { Liquefaction } \\
\text { potential }\end{array}$} & & & \multicolumn{2}{c}{$\begin{array}{c}\text { Amplification } \\
\text { potential }\end{array}$} & & \multicolumn{2}{c}{$\begin{array}{c}\text { Hazard } \\
\text { grade }\end{array}$} \\
\cline { 1 - 2 } \cline { 7 - 8 } \cline { 6 - 7 } Class & Score & & Class & Score & & Class & Score \\
\hline None & 1 & & None & 1 & & Very low & 1 \\
Low & 2 & & Low & 2 & & Low & 2 \\
Moderate & 3 & & Moderate & 3 & & Moderate & 3 \\
High & 4 & & High & 4 & & High & 4 \\
Very high & 5 & & Very high & 5 & & Very high & 5 \\
\hline
\end{tabular}

ulations of seismically hazardous areas are taken into consideration. There are four different high-hazard seismic regions identified in this study. We classified the regions in to four groups, A, B, C, and D, based on their populations (Fig. 9). Region A is located near the Porsuk River having both the highest population and high-rise buildings. Approximately 150000 people live in this region. Likewise regions B and C are located outside of the city centre but still have significant settlements. Typical buildings in this region have two or three storeys; these regions have a relatively lower population (30000) than region A. Region D is located north of the city and has almost no population.
Although limited information exists about the population and liquefaction in Ocalan's (1959) report, we know that the epicentre of the 1956 earthquake was located between the Çukurhisar and Satilmiş villages and thus outside of our present study area. The damage report prepared by the engineering corps indicates that there was significant damage to buildings located near the Porsuk River but not to those built on the rock foundation. This information actually gives a good correlation between our study and the historical data.

According to the study, the continuing development of Eskişehir should take the liquefaction and amplification hazards into account. Planning based on a single variable is based on an insufficient assessment of risk. For instance, while the north-western part of the city, that is overlain by the old alluvial, is not threatened by the liquefaction hazard, it is at high risk from amplification associated with a low shear velocity value. This is a crucial soil problem of the region that requires attention. The hazard map and the other maps should be used for an overall assessment when planning settlement in the residential area. Local drilling and comprehensive soil analyses should be performed for detailed studies and more reliable hazard assessments.

The variables of the risk assessment studies should be increased based on developing technologies and information. 


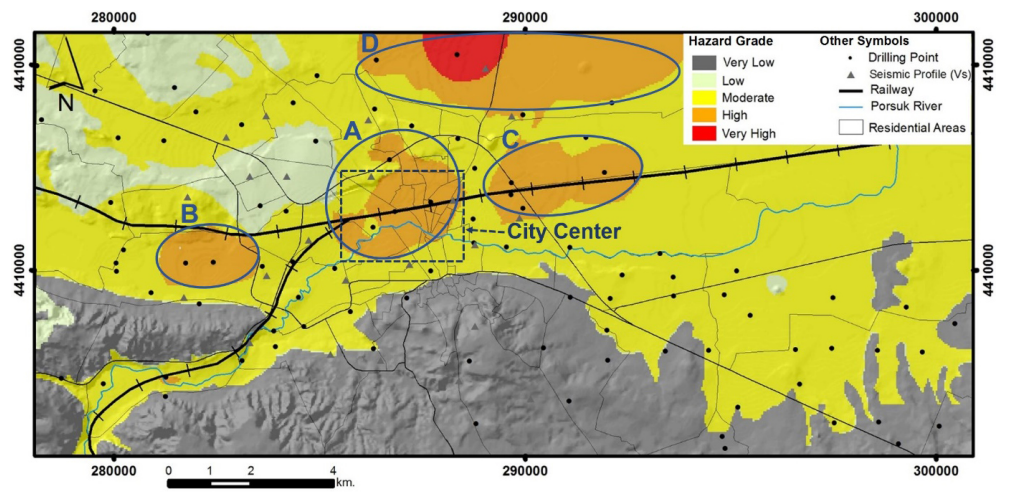

Figure 9. Hazard map produced through overlaying of liquefaction and amplification values on a given rate: high seismic risk: area A; high population with high seismic hazard; moderate seismic risk: areas B and C; significant population with high seismic hazard and low seismic risk: area D; almost no population with very high seismic hazard.

This will enable the achievement of real life solutions and prevent potential problems.

Acknowledgements. This research was supported by the Anadolu University Research Fund under Project Numbers 0802000040 and 1105F095. The editorial handling by Rosa Lasaponara and valuable comments by an anonymous reviewer have greatly improved an earlier version of this manuscript, for which we are grateful.

Edited by: R. Lasaponara

Reviewed by: B. Ecevitoğlu and two anonymous referees

\section{References}

Abrahamson, N. A. and Silva, W. J.: NGA Ground Motion Relations for the Geometric Mean Horizontal Component of Peak and Spectral Ground Motion Parameters, Final Report Prepared for the Pacific Earthquake Engineering Research Center, Pacific Earthquake Engineering Research Center, College of Engineering, University of California, Berkeley, February 2008.

ABYYHY: Afet Bölgelerinde Yapılacak Yapılar Hakkında Yönetmelik, Aydınoğlu, M. M., Bayındırlık ve İskan Bakanlığı, 1997.

Altunel, E. and Barka, A.: Neotectonic activity of Eskişehir Fault Zone between İnönü and Sultandere, Geological Bulletin of Turkey, 41, 41-52, 1998.

Akdeniz, E., Güney, Y., Pekkan, E., Avdan, U., Tün, M., and Ecevitoğlu, B.: Using Geographical Information Systems in Interpretation of Geo-Engineering Properties of Ground: Yenibağlar and Bahçelievler District Sample in Eskişehir, 6th International

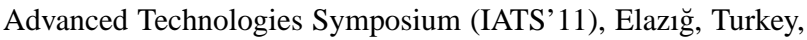
2011.

Ansal, A., Tönük, G., and Kurtuluş, A.: Zemin Büyütme Analizleri ve Sahaya Özel Tasarım Depremi Özelliklerinin Belirlenmesi, 1. Türkiye Deprem Mühendisliği ve Sismoloji Konferansı, Ankara, 2011.

Bayrakçı, E., Pekkan, E., Avdan, U., and Güney, Y.: Coğrafi Bilgi Sistemleri Kullanılarak Analiz Derinliğinin Sıvılaşma Analizine Etkisinin Belirlenmesi (Eskişehir Örneği), Harita Teknolojileri Elektronik Dergisi, 5, 50-60, 2013.
Beliceli, A.: Eskişehir Yerleşim Yeri Zeminin Büyütme Etkisinin Makaslama Dalga Hızına (Vs) Bağlı Olarak Belirlenmesi, Yüksek Lisans Tezi, Balıkesir Üniversitesi, Fen Bilimleri Enstitüsü, Türkiye, 2006.

Bell, D. H. and Pettinga, J. R.: Engineering geolology and subdivision planning in New Zealand, Eng. Geol., 22, 45-59, 1985.

Bell, F. G.: Environmental Geology, Blackwell, Malden, MA, USA, 594 pp., 1998.

Bell, F. G., Cripps, J. C., Culshaw, M. G., and O’Hara, M.: Aspects of geology in planning, in: Planning and Engineering Geology, Geological Society, London, Engineering Geology Special Publication, no. 4, edited by: Culshaw, M. G., Bell, F. G., Cripps, J. C., and O'Hara, M., The Geological Society of London, 1-38, 1987.

Bell, F. G., Culshaw, M. G., Forster, A., and Nathanail, C. P.: The engineering geology of the Notttingham area, UK, in: Engineering Geology for Tomorrow's Cities, Engineering Geology Special Publication, no. 22, edited by: Culshaw, M. G., Reeves, H. J., Jefferson, I., and Spink, T., Geological Society, London, 1-24, 2009.

Borcherdt, R. D.: Estimates of site dependent response spectra for design (methodology and justification), Earthq. Spectra, 10, 617654, 1994.

Borcherdt, R. D., Wentworth, C. M., Janssen, A., Fumal, T., and Gibbs, J.: Methodology for predictive GIS mapping of special study zones for strong ground shaking in the San Francisco bay region, in: Proc. 4th Inter. Conf. On Seismic Zonation, Stanford, California, 545-552, 1991.

Boore, D. M., Thompson, E. M., and Cadet, H.: Regional correlations of Vs30 and velocities averaged over depths less than and greater than 30 m, B. Seismol. Soc. Am., 101, 3046-3059, 2011.

Building Seismic Safety Council: Recommended Provisions for Seismic Regulations for New Buildings and Other Structures, Part 1: Provisions, Federal Emergency ManagementAgency, Washington, D.C., Report No. FEMA-450, 303 pp., 2003.

Castellaro, S., Mulargia, F., and Rossi, P. M.: Vs30: proxy for seismic amplification?, Seismol. Res. Lett., 79, 540-542, 2008.

Dai, F. C., Liu, Y., and Wang, S.: Urban geology: a case study of Tongchuan City, Shaanxi Province, China, Eng. Geol., 38, 165$175,1994$. 
Dai, F. C., Lee, C. F., and Zhang, X. H.: GIS-based geoenvironmental evaluation for urban land-use planning: a case study, Eng. Geol., 61, 257-271, 2001.

De Mulder, E. F. J.: Urban geoscience, in: Urban Geoscience, edited by: McCall, G. J. H., De Mulder, E. F. J., and Marker, B. R., Balkema, Rotterdam, 1-11, 1996.

De Mulder, E. F. J. and Pereira, J. J.: Earth science for the city, in: Engineering Geology for Tomorrow's Cities, Engineering Geology Special Publication, no. 22, edited by: Culshaw, M. G., Reeves, H. J., Jefferson, I., and Spink, T., Geological Society, London, 25-31, 2009.

Dobry, R., Borcherdt, R. D., Crouse, C. B., Idriss, I. M., Joyner, W. B., Martin, G. R., Power, M. S., Rinne, E. E., and Seed, R. B.: New site coefficients and site classification system used in recent building seismic code provisions, Earthq. Spectra, 16, 4167, 2000.

Eastman, J. R., Jin, W., Kyem, P. A. K., and Toledano, J.: Raster procedures for multi-criteria/multi-objective decisions, Photogramm. Eng. Rem. S., 61, 539-547, 1995.

Erol, G. and Topal, T.: GIS-Based Microzonation of the Niksar Settlement Area for the Purpose of Urban Planning, Environmental Earth Science, 68, 2065-2084, doi:10.1007/s12665-012-1893-7, 2012.

Eurocode 8: Design of structures for earthquake resistance, part 1: General rules, seismic actions and rules for buildings, EN 19981, European Committee for Standardization (CEN), available at: http://www.cen.eu/cenorm/homepage.htm, last access: July 2011, 2004.

Hake, S. S.: A review of engineering geological and geotechnical aspects of town and country planning with particular reference to minerals and the extractive processes, in: Planning and Engineering Geology, Geological Society Engineering Geology Special Publication, no. 4, edited by: Culshaw, M. G., Bell, F. G., Cripps, J. C., and O'Hara, M., The Geological Society, London, 69-74, 1987.

Imai, T.: $P$ and $S$ wave velocities of the ground in Japan, in: Proceeding of IX International Conference on Soil Mechanics and Foundation Engineering, 127-132, 1977.

Imai, T., Fumoto, H., and Yokota, K.: The relation of mechanical properties of soil to $P$ and $S$ wave velocities in Japan, in: Proceedings of 4th Japan Earthquake Engineering Symposium, Tokyo, Japan, 89-96, 1975.

Iwasaki, T., Tokida, K., Tatsuko, F., and Yasuda, S.: A practical method for assessing soil liquefaction potential based on case studies at various site in Japan, in: 2nd International Conference on Microzonation, San Francisco, 885-896, 1978.

Iwasaki, T., Tokida, K., Tatsuoka, F., Watanabe, S., Yasuda, S., and Sato, H.: Microzonation for soil liquefaction potential using simplified methods, in: Proceedings 3rd International Conference on Microzonation, Seattle, USA, 1319-1330, 1982.

İyisan, R.: Zeminlerde Kayma Dalgası Hızı İle Penetrasyon Deney Sonuçlarının Karşılaştırılması, İMO Teknik Dergi, 2, 11871199, 1996.

Jafari, M. K., Asghari, A., and Rahmani, I.: Empirical correlation between shear wave velocity (Vs) and SPT-N value for south of Tehran soils, in: Proceedings of the 4th International Conference on Civil Engineering, Tehran, Iran, 1997.

Joyner, W. and Fumal, T. E.: Use of measured S-wave velocity for predicting geologic site effects on strong ground motion, in: Pro- ceedings of the Eight World Conference on Earthquake Engineering, San Francisco, CA, USA, 2, 777-783, 1984.

Kılıç, H., Özener, P. T., Ansal, A., Yıldırım, M., Özaydın, K., and Adatepe, S.: Microzonation of Zeytinburnu region with respect to soil amplification: a case study, Eng. Geol., 86, 238-255, 2006.

Lee, S. H. H.: Regression models of shear wave velocities, J. Chin. Inst. Eng., 13, 519-532, 1990.

Lee, V. W. and Trifunac, M. D.: Should average shear-wave velocity in the top $30 \mathrm{~m}$ of soil be used to describe seismic amplification?, Soil Dyn. Earthq. Eng., 30, 1250-1258, 2010.

Legget, R. F.: The value of geology in planning, in: Planning and Engineering Geology, Geological Society Engineering Geology Special Publication, no. 4, edited by: Culshaw, M. G., Bell, F. G., Cripps, J. C., and O'Hara, M., The Geological Society, London, 53-58, 1987.

Malczewski, J.: GIS-based multicriteria decision analysis: a survey of the literature, Int. J. Geogr. Inf. Sci., 20, 703-726, 2006.

Marker, B. R.: Geology of megacities and urban areas, in: Engineering Geology for Tomorrow's Cities, Engineering Geology Special Publication, no. 22, edited by: Culshaw, M. G., Reeves, H. J., Jefferson, I., and Spink, T., Geological Society, London, 33-48, 2009.

Midorikawa, S.: Prediction of isoseismal map in Kanto plain due to hypothetical earthquake, Journal of Structural Engineering, 33, 43-48, 1987.

Ministry of Reconstruction and Settlement: Seismic Hazard Map of Turkey, 1996.

Mollamahmutoğlu, M. and Babuçcu, F.: Zeminlerde Sıvılaşma Analiz ve İyileştirme Yöntemleri, Gazi Kitapevi, Ankara, 2006.

Mucciarelli, M. and Gallipoli, M. R.: Comparison between VS30 and other estimates of site amplification in Italy, Paper No. 270, in: First European Conference on Earthquake Engineering and Seismology, a Joint Event of the 13th European Conference on Earthquake Engineering and 30th General Assembly of the European Seismological Commission, Geneva, Switzerland, 3-8 September 2006.

Mutlu, S.: Sismik Kırılma Yöntemi ve Mikrotremör Ölçümlerinden Elde Edilen Dinamik Zemin Parametrelerinin Coğrafi Bilgi Sistemleri (CBS) Kullanılarak Haritalanması, Yüksek Lisans Tezi, Anadolu Üni., Eskişehir, 2012.

Öcal, N.: 20 Şubat 1956 Eskişehir Zelzelesinin Makro ve Mikrosismik Etüdü, ITU Sismoloji Enstitüsü Yayını, Istanbul, Turkey, 49 pp., 1959.

Ohba, S. and Toriumi, I.: Dynamic response characteristics of Osaka plain, in: Proceedings of the Annual Meeting AIJ, Tokyo, Japan, 1970.

Ohta, Y. and Goto, N.: Empirical shear wave velocity equations in terms of characteristics soil indicies, Earthq. Eng. Struct. D., 6, 167-187, 1978.

Onur, M. I, Tün, M., Pekkan, E., and Tuncan, A.: Eskişehir İlinde Deprem Etkisi Araştırması, Uluslararası Deprem ve Yap1 Mühendisliğinde Gelişmeler Sempozyumu, Süleyman Demirel University, Isparta-Antalya, Turkey, 2007.

Orhan, A., Seyrek, E., and Tosun, H.: A probabilistic approach for earthquake hazard assessment of the Province of Eskişehir, Turkey, Nat. Hazards Earth Syst. Sci., 7, 607-614, doi:10.5194/nhess-7-607-2007, 2007. 
Park, S., Jeon, S., Kim, S., and Choi, C.: Prediction and comparison of urban growth by land suitability index mapping using GIS and RS in South Korea, Landscape Urban Plan., 99, 104-114, 2011.

Perez, O. M., Telfer, T. C., and Ross, L. G.: Use of GIS-based models for integratingand developing marine fish cages within the tourism industry in Tenerife (Canary Islands), Coastal Manage., 31, 355-366, 2003.

Pettit, C. and Pullar, D.: An integrated planning tool based upon multiple criteria evaluation of spatial information, Comput. Environ. Urban, 23, 339-357, 1999.

Rau, J. L.: Urban and environmental issues in East and Southeast Asian coastal lowlands, Eng. Geol., 37, 25-29, 1994.

Seed, H. B. and Idriss, I. M.: Simplified procedure for evaluating soil liquefaction potential, Journal of the Soil Mechanics and Foundations Division, 97, 1249-1273, 1971.

Seed, H. B. and Idriss, I. M.: Ground Motion And Soil Liquefaction During Earthquakes, Earthquake Engineering Research Institute, Oakland, California, 1982.

Seed, H. B., Tokimatsu, L. F., Harder, L. F., and Chung, R. M.: Influence of SPT procedures in soil lliquefaction resistance evaluations, J. Geotech. Eng.-ASCE, 111, 1425-1445, 1985.

Seyitoğlu, G., Ecevitoğlu, G. B., Kaypak, B., Güney, Y., Tün, M., Esat, K., Avdan, U., Temel, A., Çabuk, A., Telsiz, S., Aldaş, G. G. U.: Determining the main strand of the Eskişehir strike-slip fault zone using subsidiary structures and seismicity: a hypothesis tested by seismic reflection studies, Turk. J. Earth Sci., 24, 1-20, doi:10.3906/yer-1406-5, 2015.

Sonmez, H.: Modification of the liquefaction potential index and liquefaction susceptibility mapping for a liquefactionprone area (Inegol, Turkey), Environ. Geol., 44, 862-871, doi:10.1007/s00254-003-0831-0, 2003.
Tokay, F. and Altunel, E.: Eskişehir Fay Zonunun İnönü-Dodurga Çevresinde Neotektonik Özellikleri, MTA Dergisi, 130, 1-16, 2005.

Topal, T., Doyuran, V., Karahanoglu, N., Toprak, V., Suzen, M., and Yesilnacar, E.: Microzonation for earthquake hazards: Yenisehir settlement, Bursa, Turkey, Eng. Geol., 70, 93-108, 2003.

Tosun, H., Türköz, M., Savaş, H., Seyrek, E., and ve Orhan, A.: Eskişehir Yerleşim Alanı Güney Bölümü Temel Zemini Dinamik Davranışının İncelenmesi, Project No: 200315048, Eskişehir Osmangazi Üniversitesi Bilimsel Araştırma Projeleri Komisyonu, Eskişehir, 2007.

Tosun, H., Seyrek, E., Orhan, A., Savas, H., and Türköz, M.: Soil liquefaction potential in Eskişehir, NW Turkey, Nat. Hazards Earth Syst. Sci., 11, 1071-1082, doi:10.5194/nhess-11-10712011, 2011.

Ulamış, K. and Kılıç, R.: Liquefaction potential of quaternary alluvium in Bolu settlement area, Turkey, Environ. Geol., 55, 1029 1038, 2008.

Van Rooy, J. L. and Stiff, J. S.: Guidelines for urban engineering geological investigations in South Africa, B. Eng. Geol. Environ., 59, 285-295, 2001.

Youd, T. L., Idriss, I. M., Andrus, R. D., Arango, I., Castro, G., Christian, J. T., Dobry, R., Finn, W. D. L., Harder, L. F., Hynes, M. E., Ishihara, K., Koester, J. P., Liao, S. S. C., Marcuson, W. F., Martin, G. R., Mitchell, J. K., Moriwaki, Y., Power, M. S., Robertson, K., Seed, R. B., and Stokoe, K. H.: Liquefaction resistance of soils: summary report from the 1996 NCEER and 1998 NCEER/NSF workshops on evaluation of liquefaction resistance of soils, J. Geotech. Geoenviron., 127, 817-833, 2001. 